\title{
An early $A C L$ reconstruction is required to prevent additional knee injury: A misconception not supported by high-quality evidence
}

\author{
Dr Stephanie Filbay, B.Phty(Hons), PhD \\ Arthritis Research UK Centre for Sport, Exercise and Osteoarthritis \\ Nuffield Department of Orthopaedics, Rheumatology and Musculoskeletal Sciences, \\ University of Oxford. Windmill Rd. Oxford, UK. OX37LD
}

It is evident that meniscus injury is associated with increased rates of osteoarthritis and joint replacement surgery, and that preserving the meniscus should be a key priority when managing ACL-injured individuals. A common belief within the orthopaedic community is that early ACL-reconstruction is necessary to prevent additional meniscus and cartilage injury. ${ }^{1}$ The studies referenced to support this argument (Table 1) are limited by selection and indication bias. Whilst these studies highlight the importance of managing ACL injury early to preserve joint health, they do not provide evidence that early-reconstruction is superior to 'evidence-based rehabilitation ${ }^{21}$ in reducing subsequent meniscus or cartilage injury rates. Referenced studies share a similar conclusion; that people who present for early-reconstruction shortly after $\mathrm{ACL}$ injury have less meniscus or cartilage damage than those who present for ACL-reconstruction months or years after injury (Table 1). This is not surprising, individuals who are chronically ACL-deficient may have been incorrectly diagnosed or exposed themselves to sport or other high-risk activities for months or years, without undertaking appropriate rehabilitation. Importantly, studies that found more meniscus or cartilage damage in patients presenting for a delayed-reconstruction (following unknown treatment/no treatment) compared with patients presenting for an earlyreconstruction, should not be used to justify recommending early $A C L$ reconstruction over management of an acute $A C L$ injury with evidence-based rehabilitation.

Randomised controlled trials (RCTs) are required to compare rates of subsequent injury between ACL management strategies. These studies should assess all patients for concomitant injuries prior to commencing either treatment strategy and the rehabilitation received should commence early after $A C L$ injury and be high quality, evidence-based rehabilitation. A recent review found that only 1 of 412 ACL RCTs compared ACLreconstruction with structured rehabilitation for acute $A C L$ injury. ${ }^{3}$ The KANON Trial, is a high-quality RCT that compared outcomes following early-reconstruction plus exercise therapy, or exercise therapy plus optional delayed-reconstruction if required and/or desired. ${ }^{2}$ The KANON trial found no differences in activity levels, patient-reported outcomes or radiographic joint changes at two- and five-year follow-up between randomised groups and as-treated groups (early-reconstruction vs. exercise therapy alone vs. delayedreconstruction). ${ }^{2}$ Additionally, the proportion of people receiving meniscus surgery within five-years of $A C L$ injury was similar between groups. ${ }^{24}$ On further analysis, we found that 
baseline meniscus and cartilage injury was only related to poor five-year outcome (poor knee function and quality of life) for individuals randomised to early-reconstruction, and that commencing exercise therapy before considering ACL-reconstruction may be advantageous for these patients. ${ }^{5}$ Additionally, early-reconstruction predicted more knee symptoms at five-years compared with management with rehabilitation alone, and poor baseline knee scores were only related to poor five-year outcome for individuals who underwent early ACL-reconstruction. ${ }^{5}$ Further evidence that commencing evidence-based rehabilitation before considering ACL-reconstruction does not have negative impacts on outcome can be drawn from studies showing superior postoperative knee scores and function in patients who perform prehabilitation prior to undergoing $A C L$ reconstruction. ${ }^{67}$

We know that rates of subsequent knee injury are high following $A C L$ reconstruction. One out of every three young people who undergo $A C L$ reconstruction suffer a second $A C L$

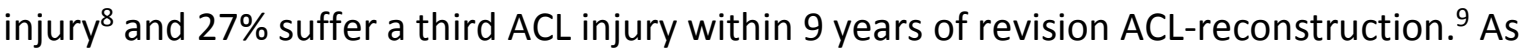
many as $90 \%$ of individuals will damage the meniscus or cartilage at the time of ACL graftrupture. ${ }^{10}$ Additionally, the risk of meniscus surgery remains higher for the ACLreconstructed knee compared with the contralateral knee, even in individuals who do not rupture their $\mathrm{ACL}$ graft. ${ }^{11}$ Research over a 10-year period found that $\mathrm{ACL}$-reconstructed individuals experienced more second $\mathrm{ACL}$ injuries than those who elected to undergo nonoperative management. ${ }^{12}$ This remained the case when graft-ruptures were excluded from the analysis, highlighting that ACL-reconstructed individuals were at greater risk of contralateral ACL injury than their non-operatively managed counterparts. Grindem et al. (2014) found a greater proportion of ACL-reconstructed individuals reinjured their knee within 2 years of ACL rupture (24\%) compared with patients managed with physiotherapistsupervised rehabilitation (9\%). ${ }^{13}$ After adjusting for rates of return to pivoting-sports, there were no differences in subsequent knee injury rates between ACL-treatment groups, suggesting that the observed difference was largely explained by the higher rate of return to sport in ACL-reconstructed patients.

Returning to pivoting-sport is not the only modifiable factor associated with an increased risk of subsequent knee injury after $\mathrm{ACL}$ reconstruction. Fear of re-injury, suboptimal knee function prior to returning to sport, and returning to sport within 9 months of ACLreconstruction, have been associated with increased odds of sustaining a subsequent knee injury. ${ }^{141516}$ This highlights that there are other factors to consider, aside from selecting an operative or non-operative ACL-management strategy, to reduce the likelihood of further knee injury. Individuals who do not participate in pivoting sports after $A C L$ injury will reduce their risk of subsequent knee injury, highlighting the importance of educating the patient to enable them to make an informed decision regarding activity choices. If an individual decides to return to pivoting-sport, ensuring they are both psychologically and physically ready can reduce the risk of subsequent knee injury. These modifiable factors associated with an increased risk of subsequent injury should be targeted after ACL injury, irrespective of ACL-management strategy. 
There is no high-quality evidence to suggest rates of subsequent knee injury are higher following management with evidence-based rehabilitation compared with early ACLreconstruction. It is critical that clinical recommendations are based on appropriate evidence, derived from studies using an appropriate study design and statistical analysis to address the study question. Retrospective observational studies showing more joint injury at the time of delayed ACL-reconstruction (following unknown treatment/no treatment) should not be used to justify favouring early-reconstruction over management with evidence-based rehabilitation. Rather, evidence supports the importance of managing an $A C L$ rupture as soon as possible following injury to prevent further knee damage and subsequent osteoarthritis. To minimise the likelihood of subsequent injury, and thereby improve long-term outcome and reduce osteoarthritis risk, clinicians should educate patients regarding activity modification, and optimise psychological readiness and physical function before returning to sport, irrespective of $A C L$-management strategy. The high rates of second and third ACL injuries following ACL-reconstruction are concerning, as are the implications for long-term joint health for these individuals. This risk should be discussed with patients when informing them of the evidence surrounding ACL management options. 
Table 1. Studies commonly referenced to support the belief that an early-ACL reconstruction is required to reduce the likelihood of subsequent knee injury

\begin{tabular}{|c|c|c|c|c|c|}
\hline Study & Sample & $\begin{array}{l}\text { Management } \\
\text { between } A C L \\
\text { injury and } \\
\text { ACLR }\end{array}$ & $\begin{array}{l}\text { Appropriateness of } \\
\text { study design to } \\
\text { inform } \mathrm{ACL} \\
\text { management choice }\end{array}$ & Statistical analysis & Authors' interpretation of findings \\
\hline $\begin{array}{l}\text { Karikis et } \\
\text { al. } 2018 \\
{[1]}\end{array}$ & $\begin{array}{l}\text { Patients } \\
\text { undergoing } \\
\text { ACLR }\end{array}$ & Unknown & Inappropriate & $\begin{array}{l}\text { Chi-square or Fisher's } \\
\text { exact test, no adjustment } \\
\text { for confounding }\end{array}$ & $\begin{array}{l}\text { Patients who underwent ACLR 2-4 months after injury required fewer } \\
\text { meniscectomies at the time of ACLR and had less OA at } 10 \text {-year follow-up compared } \\
\text { with those who underwent ACLR } 24-48 \text { months after injury. The authors suggest } \\
\text { that ACLR should be performed before concomitant lesions occur. }\end{array}$ \\
\hline $\begin{array}{l}\text { Sanders et } \\
\text { al. } 2016 \\
{[2]}\end{array}$ & $\begin{array}{l}\text { Review of } \\
\text { surgical } \\
\text { records }\end{array}$ & Unknown & Inappropriate & $\begin{array}{l}\text { Cox proportional } \\
\text { hazards regression, no } \\
\text { adjustment for } \\
\text { confounding }\end{array}$ & $\begin{array}{l}\text { ACLR }<12 \text { months after injury reduced the risk of subsequent meniscal tears and } O A \\
\text { compared with } A C L R>12 \text { months after injury. The authors concluded that } A C L R \text { has } \\
\text { a lower risk of secondary meniscal tears, OA and TKA compared to non-operative } \\
\text { treatment. }\end{array}$ \\
\hline $\begin{array}{l}\text { De } \\
\text { Campos et } \\
\text { al. } 2016 \\
\text { [3] }\end{array}$ & $\begin{array}{l}\text { Review of } \\
\text { surgical } \\
\text { records }\end{array}$ & Unknown & Inappropriate & $\begin{array}{l}\text { Chi-square or Fisher's } \\
\text { exact test and logistic } \\
\text { regression, no } \\
\text { adjustment for } \\
\text { confounding }\end{array}$ & $\begin{array}{l}\text { Associated injuries are more common if } A C L R \text { is delayed by } \geq 6 \text { months (medial } \\
\text { meniscus lesion) and } \geq 1 \text { year (cartilage or meniscal lesion). High-quality evidence } \\
\text { based data such as randomised controlled trials are needed. }\end{array}$ \\
\hline $\begin{array}{l}\text { Ralles et } \\
\text { al. } 2015 \\
{[4]}\end{array}$ & $\begin{array}{l}\text { Review of } \\
\text { surgical } \\
\text { records }\end{array}$ & Unknown & Inappropriate & $\begin{array}{l}\text { Chi-square test and linear } \\
\text { regression, no } \\
\text { adjustment for } \\
\text { confounding }\end{array}$ & $\begin{array}{l}\text { Increasing time from injury to ACLR was associated with increased incidence of } \\
\text { cartilage and medial meniscus injury. Subject to selection bias; individuals that had } \\
\text { delayed ACLR had probably failed non-operative treatment, whereas those } \\
\text { successfully managed non-operatively were not included in the study. }\end{array}$ \\
\hline $\begin{array}{l}\text { Krutsch et } \\
\text { al. } 2015 \\
{[5]}\end{array}$ & $\begin{array}{l}\text { Review of } \\
\text { ACLR } \\
\text { registry }\end{array}$ & Unknown & Inappropriate & $\begin{array}{l}\text { Chi-square or Fisher's } \\
\text { exact test, no adjustment } \\
\text { for confounding }\end{array}$ & $\begin{array}{l}\text { Due to the higher rate of surgically repairable meniscal injury in patients having } \\
A C L R<6 \text { months after injury, authors recommend having } A C L R<6 \text { months after } \\
\text { injury to preserve the meniscus and reduce the risk of developing OA. }\end{array}$ \\
\hline $\begin{array}{l}\text { Sri-Ram et } \\
\text { al. } 2013 \\
{[6]}\end{array}$ & $\begin{array}{l}\text { Patients } \\
\text { undergoing } \\
\text { ACLR }\end{array}$ & Unknown & Inappropriate & $\begin{array}{l}\text { Logistic regression, no } \\
\text { adjustment for } \\
\text { confounding }\end{array}$ & $\begin{array}{l}\text { The chances of requiring medial meniscal surgery was increased by a factor of two if } \\
\text { ACLR was delayed }>5 \text { months, and increased by a factor of } 6 \text { if delayed }>12 \text { months. } \\
\text { The authors conclude that ideally, ACLR should not be delayed }>5 \text { months from } \\
\text { injury. Notably, patients treated conservatively were excluded from the study. }\end{array}$ \\
\hline $\begin{array}{l}\text { Fok \& Yau } \\
2013 \text { [7] }\end{array}$ & $\begin{array}{l}\text { Patients } \\
\text { undergoing } \\
\text { ACLR }\end{array}$ & Unknown & Inappropriate & $\begin{array}{l}\text { Student's } t \text {-test and } \\
\text { logistic regression, no }\end{array}$ & $\begin{array}{l}\text { ACLR } \leq 12 \text { months after injury was associated with more meniscus and cartilage } \\
\text { injury and the meniscus was less likely to be salvageable. Authors recommend } \\
\text { informing patients that } A C L R \text { delay is associated with increased joint injury. Biases }\end{array}$ \\
\hline
\end{tabular}




\begin{tabular}{|c|c|c|c|c|c|}
\hline & & & & $\begin{array}{l}\text { adjustment for } \\
\text { confounding }\end{array}$ & $\begin{array}{l}\text { acknowledged include the exclusion of patients managed non-operatively and no } \\
\text { information on what patients were doing between injury and ACLR. }\end{array}$ \\
\hline $\begin{array}{l}\text { Anstey et } \\
\text { al. } 2012 \\
\text { [8] }\end{array}$ & $\begin{array}{l}\text { Review of } \\
\text { surgical } \\
\text { records }\end{array}$ & Unknown & Inappropriate & $\begin{array}{l}\text { Fisher's exact test, no } \\
\text { adjustment for } \\
\text { confounding }\end{array}$ & $\begin{array}{l}\text { A delay in the timing of } A C L R>6 \text { months following injury is associated with an } \\
\text { increase in the prevalence of medial meniscal tears. The authors highlight the need } \\
\text { for a randomised controlled trial to evaluate the degree of joint injury relative to } \\
\text { timing of ACLR. }\end{array}$ \\
\hline $\begin{array}{l}\text { Chhadia et } \\
\text { al. } 2011 \\
{[9]}\end{array}$ & $\begin{array}{l}\text { Review of } \\
\text { ACLR } \\
\text { registry }\end{array}$ & Unknown & Inappropriate & $\begin{array}{l}\text { Chi-square or Fisher's } \\
\text { exact test, logistic } \\
\text { regression adjusted for } \\
\text { age and gender }\end{array}$ & $\begin{array}{l}\text { Increased risk of medial meniscus and cartilage injury and a decreased meniscal } \\
\text { repair rate were strongly associated with increased ACLR delay. Patients who } \\
\text { elected to undergo non-operative treatment were excluded from the study } \\
\text { resulting in selection bias. }\end{array}$ \\
\hline $\begin{array}{l}\text { Kennedy } \\
\text { et al. } 2010 \\
{[10]}\end{array}$ & $\begin{array}{l}\text { Review of } \\
\text { surgical } \\
\text { records }\end{array}$ & Unknown & Inappropriate & $\begin{array}{l}\text { Chi-square test, Mantel- } \\
\text { Haenszel method } \\
\text { adjusted for age }\end{array}$ & $\begin{array}{l}\text { Higher chance of medial meniscus injury with ACLR delay }>12 \text { months; degenerative } \\
\text { changes were more common with ACLR delay }>6 \text { months; the authors recommend } \\
\text { that ACLR be performed within } 12 \text { months of injury. }\end{array}$ \\
\hline $\begin{array}{l}\text { Granan et } \\
\text { al. } 2009 \\
{[11]}\end{array}$ & $\begin{array}{l}\text { Review of } \\
\text { ACLR } \\
\text { registry }\end{array}$ & Unknown & Inappropriate & $\begin{array}{l}\text { Logistic regression, } \\
\text { adjusted for age, sex, } \\
\text { prior knee surgery, } \\
\text { current ligament injury, } \\
\text { meniscal/cartilage lesions }\end{array}$ & $\begin{array}{l}\text { Early ACLR was associated with fewer meniscal tears and cartilage injuries; } \\
\text { however, some patients may benefit from prehabilitation or management with } \\
\text { rehabilitation. }\end{array}$ \\
\hline $\begin{array}{l}\text { Keene et } \\
\text { al. } 1993 \\
{[12]}\end{array}$ & $\begin{array}{l}\text { Review of } \\
\text { surgical } \\
\text { records }\end{array}$ & Unknown & Inappropriate & Chi-square test & $\begin{array}{l}\text { The incidence of meniscus injury increased with a greater ACLR delay and meniscal } \\
\text { tears became more complex and less amendable; the authors recommend surgery } \\
\text { be considered early. }\end{array}$ \\
\hline
\end{tabular}

OA: osteoarthritis; ACLR: anterior cruciate ligament reconstruction; TKA: total knee arthroplasty;

[1] Karikis et al. The Long-Term Outcome After Early and Late ACL Reconstruction. Arthroscopy 2018;34(6):1907-17.

[2] Sanders et al. Is ACL Reconstruction Effective in Preventing Secondary Meniscal Tears and Osteoarthritis? Am J Sports Med 2016;44(7):1699-707.

[3] De Campos et al. Association Between Meniscal and Chondral Lesions and Timing of ACL Reconstruction. Orthop J Sports Med 2016;4(10):2325967116669309.

[4] Ralles. Incidence of secondary intra-articular injuries with time to ACL reconstruction. Am J Sports Med. 2015;43:1373-1379.

[5] Krutsch et al. Timing of ACL reconstruction within the first year after trauma and its influence on treatment of cartilage and meniscus pathology. Knee Surg Sports Traumatol Arthrosc 2015

[6] Sri-Ram et al. The incidence of secondary pathology after ACL rupture in 5086 patients requiring ligament reconstruction. The bone \& joint journal 2013;95-B(1):59-64.

[7] Fok \& Yau. Delay in ACL reconstruction is associated with more severe and painful meniscal and chondral injuries. Knee Surg Sports Traumatol Arthrosc 2013;21(4):928-33.

[8] Anstey et al. Effect of timing of ACL reconstruction in surgery and development of meniscal and chondral lesions. The Physician and sportsmedicine 2012;40(1):36-40.

[9] Chhadia et al. Are meniscus and cartilage injuries related to time to anterior ACL reconstruction? Am J Sports Med. 2011;39:1894-1899.

[10] Kennedy et al. Timing of reconstruction of the ACL in athletes and the incidence of secondary pathology within the knee. J Bone Joint Surg Br 2010;92(3):362-6.

[11] Granan et al. Timing of ACL reconstructive surgery and risk of cartilage lesions and meniscal tears: a cohort study based on the Norwegian National Knee Ligament Registry. Am J Sports Med 2009;37(5):955-61.

[12] Keene et al. The natural history of meniscal tears in ACL insufficiency. Am J Sports Med 1993;21(5):672-9. 


\section{References}

1. Siegel MG. Editorial Commentary: "Defer No Time, Delays Have Dangerous Ends" (Henry VI, Shakespeare): Delayed Anterior Cruciate Ligament Reconstruction Has Consequences. Arthroscopy 2018;34(6):1918-20. doi: 10.1016/j.arthro.2018.02.017 [published Online First: 2018/05/29]

2. Frobell RB, Roos EM, Roos HP, et al. A randomized trial of treatment for acute anterior cruciate ligament tears. N Engl J Med 2010;363(4):331-42.

3. Kay J, Memon M, Sa D, et al. A Historical Analysis of Randomized Controlled Trials in Anterior Cruciate Ligament Surgery. Bone Joint Surg Am 2017;99(24):2062-68. doi: 10.2106/jbjs.16.01408

4. Frobell RB, Roos HP, Roos EM, et al. Treatment for acute anterior cruciate ligament tear: five year outcome of randomised trial. BMJ 2013;346(jan24 1):f232-f32. doi: 10.1136/bmj.f232

5. Filbay SR, Roos EM, Frobell RB, et al. Delaying ACL reconstruction and treating with exercise therapy alone may alter prognostic factors for 5-year outcome: an exploratory analysis of the KANON trial. Br J Sports Med 2017 doi: 10.1136/bjsports-2016-097124

6. Shaarani SR, O'Hare C, Quinn A, et al. Effect of Prehabilitation on the Outcome of Anterior Cruciate Ligament Reconstruction. Am J Sports Med ne 2013 doi: $10.1177 / 0363546513493594$

7. Grindem H, Granan LP, Risberg MA, et al. How does a combined preoperative and postoperative rehabilitation programme influence the outcome of $A C L$ reconstruction 2 years after surgery? A comparison between patients in the Delaware-Oslo ACL Cohort and the Norwegian National Knee Ligament Registry. Br J Sports Med 2015;49(6):385-9. doi: 10.1136/bjsports-2014-093891

8. Webster KE, Feller JA. Exploring the High Reinjury Rate in Younger Patients Undergoing Anterior Cruciate Ligament Reconstruction. Am J Sports Med 2016;44(11):2827-32. doi: 10.1177/0363546516651845

9. Webster KE, Feller JA, Kimp AJ, et al. Revision Anterior Cruciate Ligament Reconstruction Outcomes in Younger Patients: Medial Meniscal Pathology and High Rates of Return to Sport Are Associated With Third ACL Injuries. Am J Sports Med 2018;46(5):1137-42. doi: 10.1177/0363546517751141

10. Wright RW, Huston LJ, Spindler KP, et al. Descriptive epidemiology of the Multicenter ACL Revision Study (MARS) cohort. Am J Sports Med 2010;38(10):1979-86. doi: 10.1177/0363546510378645

11. Davis BR, Chen J, Inacio MCS, et al. The Incidence of Subsequent Meniscal Surgery Is Higher in the Anterior Cruciate Ligament-Reconstructed Knee Than in the Contralateral Knee. Am J Sports Med 2017;45(14):3216-22. doi: 10.1177/0363546517721685

12. Schilaty ND, Bates NA, Sanders TL, et al. Incidence of Second Anterior Cruciate Ligament Tears (1990-2000) and Associated Factors in a Specific Geographic Locale. Am J Sports Med 2017;45(7):1567-73. doi: 10.1177/0363546517694026

13. Grindem H, Eitzen I, Engebretsen L, et al. Nonsurgical or Surgical Treatment of ACL Injuries: Knee Function, Sports Participation, and Knee Reinjury: The Delaware-Oslo ACL Cohort Study. Bone Joint Surg Am 2014;96(15):1233-41. doi: 10.2106/jbjs.m.01054

14. Paterno MV, Flynn K, Thomas S, et al. Self-Reported Fear Predicts Functional Performance and Second ACL Injury After ACL Reconstruction and Return to Sport: A Pilot Study. Sports Health 2018;10(3):228-33. doi: 10.1177/1941738117745806

15. Grindem H, Snyder-Mackler L, Moksnes H, et al. Simple decision rules can reduce reinjury risk by $84 \%$ after ACL reconstruction: the Delaware-Oslo ACL cohort study. Br J Sports Med 2016;50(13):804-8. doi: 10.1136/bjsports-2016-096031

16. Kyritsis $P$, Bahr R, Landreau $P$, et al. Likelihood of $A C L$ graft rupture: not meeting six clinical discharge criteria before return to sport is associated with a four times greater risk of rupture. Br J Sports Med 2016;50(15):946-51. doi: 10.1136/bjsports-2015-095908 
